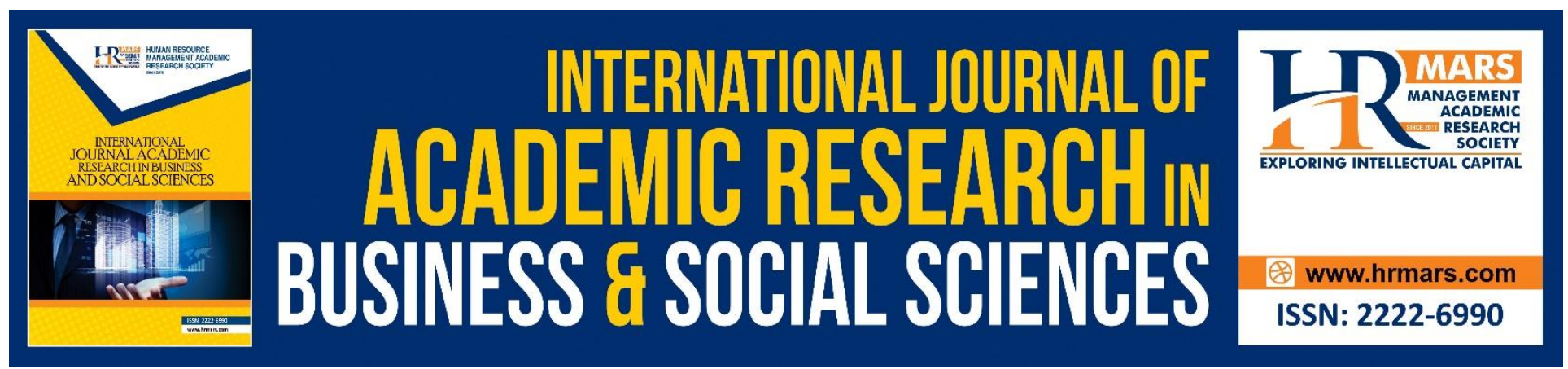

\title{
Approaches Used by ESL Lecturers in Promoting Learner Autonomy in Institute of Teacher Education
}

Fauziah Ismail

Melor Md Yunus

Azizah Mohd Zahidi

To Link this Article: http://dx.doi.org/10.6007/IJARBSS/v8-i12/5429

DOI: $10.6007 /$ IJARBSS/v8-i12/5429

Received: 11 Nov 2018, Revised: 18 Dec 2018, Accepted: 26 Dec 2018

Published Online: 06 Dec 2018

In-Text Citation: (Ismail, Yunus, \& Zahidi, 2018)

To Cite this Article: Ismail, F., Yunus, M. M., \& Zahidi, A. M. (2018). Approaches Used by ESL Lecturers in Promoting Learner Autonomy in Institute of Teacher Education. International Journal of Academic Research in Business and Social Sciences, 8(12), 2175-2182.

Copyright: (c) 2018 The Author(s)

Published by Human Resource Management Academic Research Society (www.hrmars.com)

This article is published under the Creative Commons Attribution (CC BY 4.0) license. Anyone may reproduce, distribute, translate and create derivative works of this article (for both commercial and non-commercial purposes), subject to full attribution to the original publication and authors. The full terms of this license may be seen

at: http://creativecommons.org/licences/by/4.0/legalcode

Vol. 8, No. 12, 2018, Pg. 2175 - 2182

http://hrmars.com/index.php/pages/detail/IJARBSS

JOURNAL HOMEPAGE

Full Terms \& Conditions of access and use can be found at http://hrmars.com/index.php/pages/detail/publication-ethics 


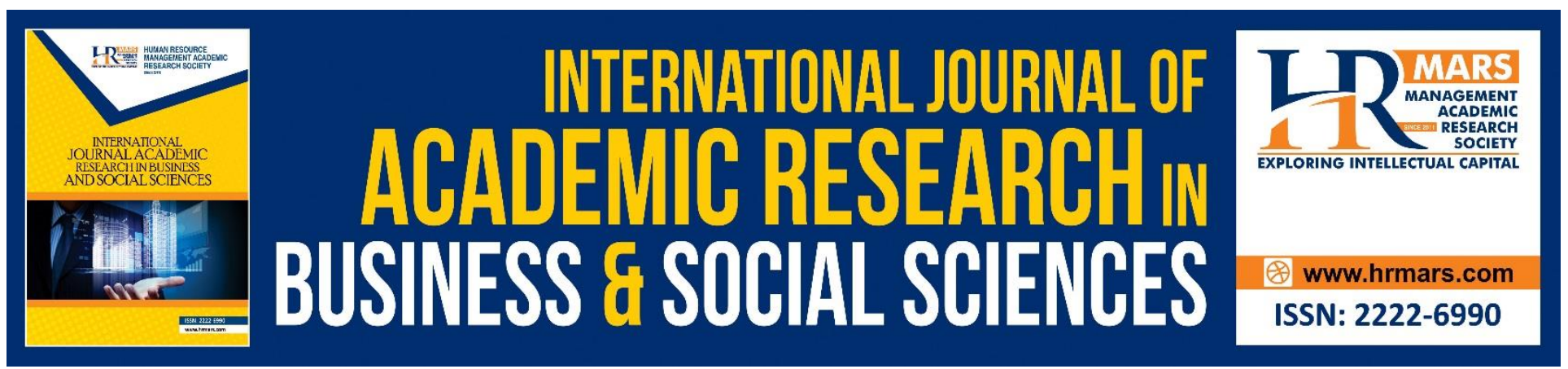

\title{
Approaches Used by ESL Lecturers in Promoting Learner Autonomy in Institute of Teacher Education
}

\author{
Fauziah Ismail \\ Institut Pendidikan Guru, Kampus Pendidikan Islam, Malaysia \\ Melor Md Yunus \\ Universiti Kebangsaan Malaysia, Malaysia \\ Azizah Mohd Zahidi \\ Universiti Kebangsaan Malaysia, Malaysia
}

\begin{abstract}
Autonomous learners are synonymous with successful language learners. Language educators with a repertoire of teaching styles, approaches and strategies would facilitate language learners to become autonomous. The present study aims to explore the approaches used by the ESL lecturers in promoting learner autonomy in teacher training context besides the strategies used for each approach. The participants of the study were 74 ESL lecturers from Institute of Teacher Education (ITE) campuses in Malaysia. A survey questionnaire adapted from Borg and Busaidi (2012) was used for data collection. The analysis revealed that multiple approaches (more than one) were used by these ESL lecturers in promoting learner autonomy. Technology-based ranked the highest, followed by resource-based, learner-based, classroom-based, curriculum-based and the least, teacher-based. The findings also revealed seven main categories from the strategies used among these ESL lecturers where the most commonly used strategy is to incorporate various learning materials and resources. This implied that majority of the ESL lecturers in ITE provided opportunities to their students to become autonomous based on their perspectives of learner autonomy that are manifested through the strategic approaches used in their teaching practices.
\end{abstract}

Keywords: Learner Autonomy, Approaches, Strategies, Teacher Training, Institute Of Teacher Education.

\section{Introduction}

Up to date, much has been written and studied on learner autonomy particularly in language learning pertaining its importance, beliefs, practices as well as the relationship with other variables and many more. Learner autonomy can be described as the capability of the learner to take control 
of his or her own learning. The idea of autonomous language learning (ALL) is a shift or transition from teacher-centred to learner-centred where the learner is fully involved in the learning process. However, it doesn't mean they are totally on their own. The learning is co-constructed where the teacher plays an important role to facilitate the learning. As claimed by Benson (2007), the aim of learning is to create an autonomous learners. With the emergence of $21^{\text {st }}$ century learning and $4^{\text {th }}$ Industrial Revolution, having autonomous learners seem to be ideal in order to have a meaningful and authentic learning which focuses on the learners' success not only in learning the language, but as well as in other subjects and aspects of life too.

The term learner autonomy was coined by Holec (1981) as an "ability to take charge of one's own learning" (p.3). His influential definition was followed by several attempts to describe autonomy. Little (1991) described autonomy as "a capacity for detachment, critical reflection, decision making and independent action" (p.4), while Littlewood (1996) defined autonomy as "learner's ability and willingness to make choices independently" (p. 427). Benson (2013) stated learner autonomy as "the capacity to take control over learning" (p. 61). Despite of various definitions of learner autonomy in the literature, it can be agreed that learner autonomy is concerned with the learner's ability and willingness to take the responsibility for their own learning and make decisions to set their own objectives, plan their own strategies, monitor and evaluate their own learning progress.

In Malaysia, there were few studies conducted on learner autonomy focusing on the educators' practices. A study conducted by Yunus and Arshad (2014) revealed that the teachers have positive opinions towards autonomous language learning (ALL) in terms of its implementation despite of the discouraging situation among students who may not all are equally ready for ALL especially in terms of taking responsibility in multi-cultural classrooms. Looking from the teachers' perspective too, Hasim and Zakaria (2016) conducted a study on Malaysian ESL teachers on how autonomy is conceptualized, perceived and practiced. The result of the study revealed that even though the ESL teachers were aware of the learner autonomy concepts, quite a number were uncertain of the attributes of autonomous learners. Dwee and Anthony (2017) conducted a qualitative study exploring the perceptions and practices of university teachers in fostering learner autonomy. The findings revealed that the university teachers were lack of focus in terms of developing learner autonomy in the classroom even though they possessed a fair understanding of what learner autonomy is, due to some challenges. These current studies indicated that there is a mismatch between perspectives and practices in promoting learner autonomy among the ESL teachers and warrants further research to be conducted.

As highlighted in Malaysian Education Blueprint (MEB 2013-2025), the use of ALL to improve proficiency among students and to make ITE as the world-class teacher training university, training is particularly an important mechanism for improving the quality of teachers. With limited studies of the current practices of the ESL lecturers in promoting learner autonomy at ITE, therefore, there is a need to explore and gain more insights from the lecturers of ITE as they are the ones who are responsible in training the future primary school teachers nationwide with the fundamental pedagogical knowledge and skills. It is hoped that this present study will provide us with better understanding of the practices in promoting learner autonomy in teacher training context where the 
INTERNATIONAL JOURNAL OF ACADEMIC RESEARCH IN BUSINESS AND SOCIAL SCIENCES

Vol. 8, No. 12, Dec, 2018, E-ISSN: 2222-6990 @ 2018 HRMARS

ESL lecturers are not only teaching them about the language, but as well to train them to become autonomous learners.

\section{Approaches in Promoting Learner Autonomy}

Benson (2011) recognized that autonomy has multiple dimensions and many different forms depending on the person and on the contextual factors. Learners show autonomous behaviours in various ways, which lead to different approaches to autonomy that should be followed to foster LA in particular contexts. Thus, there is no single approach in fostering learner autonomy. As suggested by Benson (2001, p. 111), there are at least six broad headings to classify 'approaches to the development of learner autonomy':

- Resource-based approach refers to the independent engagement with learning materials and resources.

- Technology-based approach emphasizes the inclusion of educational technologies in the teaching and learning.

- Learner-based approach focuses the importance of teaching learners to improve their learning skills and strategies.

- Classroom-based approach gives learners' the empowerment to plan and evaluate the classroom learning.

- Curriculum-based approach extends the idea where learners are expected to make major decisions concerning the content and procedures of learning, with the support of their teachers.

- Teacher-based approach focuses on the teacher's roles in fostering learner autonomy among language learners.

\section{Methodology}

The present survey-based research aimed to identify the approaches and strategies used by ESL lecturers in promoting learner autonomy in teaching English at Institute of Teacher Education. A questionnaire which was adapted from Borg and Busaidi (2012) were used to gather the data. In Section 5 of the questionnaire, the lecturers were asked to choose the approaches they employed from the options given and explain in an open-ended manner of the strategies they used in promoting learner autonomy in their classroom. The initial data on approaches were tabulated and analyzed descriptively through frequencies and percentages, supported with some explanations from the lecturers of the strategies used in promoting learner autonomy in ITE which provided a substantial amount of qualitative data to complement the quantitative data. The questionnaire was administered to a group of 74 ESL lecturers, serving at seven campuses of Institutes of Teacher Education in Malaysia. The data collection took almost 4 weeks during the 2 nd semester of the academic year.

\section{Findings and Discussion}

This study aimed to identify the approaches used by the ESL lecturers in promoting learner autonomy in ITE as well as the specific strategies used in their teaching practice. Firstly, the findings 
INTERNATIONAL JOURNAL OF ACADEMIC RESEARCH IN BUSINESS AND SOCIAL SCIENCES

Vol. 8, No. 12, Dec, 2018, E-ISSN: 2222-6990 @ 2018 HRMARS

are presented on the approaches used as suggested by Benson (2001), followed by the strategies applied by the ESL lecturers in promoting learner autonomy for each approach.

Results are presented in Table 1.

Table 1. The approaches used in promoting learner autonomy by ESL lecturers $(\mathbf{N}=\mathbf{7 4})$.

\begin{tabular}{ccccccc}
\hline Approaches & $\begin{array}{c}\text { Resource- } \\
\text { based }\end{array}$ & $\begin{array}{c}\text { Technology- } \\
\text { based }\end{array}$ & $\begin{array}{c}\text { Curriculum- } \\
\text { based }\end{array}$ & $\begin{array}{c}\text { Classroom- } \\
\text { based }\end{array}$ & $\begin{array}{c}\text { Learner- } \\
\text { based }\end{array}$ & $\begin{array}{c}\text { Teacher- } \\
\text { based }\end{array}$ \\
\hline $\mathrm{N}$ & 50 & 56 & 26 & 25 & 48 & 19 \\
$\%$ & 67.6 & 75.7 & 35.1 & 33.8 & 64.9 & 25.7 \\
\hline
\end{tabular}

From the survey, as noted in Table 1, it was identified that a majority of $75.7 \%(n=56)$ has chosen technology-based approach, followed by resource-based approach with $67.6 \%(n=50)$. Learner-based approach ranked the third with $64.9 \%(n=48)$, followed by curriculum-based with $35.1 \%(n=26)$ and classroom-based with $33.8 \%(n=25)$. The least used approach is teacher-based approach with a response of $25.7 \%(n=19)$. The research findings in Table 1 highlights few interesting facts.

Firstly, the findings revealed that the ESL lecturers in ITE employed more than one or multiple approaches in promoting learner autonomy. The choices of approaches used could be due to their preference of teaching styles in which they can actually adapt and adopt to the students' needs and learning styles. When the lecturers employed multiple approaches, it could be concluded that they are more likely to be knowledgeable, effective and professional in their profession where the lecturer's knowledge and understanding of learner autonomy are reflected in the approaches used in fostering autonomous behaviours in language learning.

Secondly, Table 1 further revealed that technology-based approach ranked the most employed approach by the ESL lecturers. This suggests that the ESL lectures embrace the technology well in their teaching practices. Promoting learner autonomy while teaching English through technology-based approach has provided an avenue where both lecturers and students can make the teaching and learning effective and meaningful. It serves as an alternative to self-assess centers. Thus, it provides learners with the opportunities to be responsible and take charge of their own learning, therefore it has a strong potential to develop autonomous behaviours (Benson, 2001). Within the framework of technology-based approaches, the lecturers are seen as advisors who offer possibilities, encourage their learners to use self-access centres, provide learners with strategies supporting the process of autonomous learning, facilitate the students to overcome the difficulties in using-technology based resources and serve as a compass in orientation among huge amount of resources (Arikan\& Bakia, 2011; Luzon \& Ruiz-Madrid, 2008; Tassinari, 2012).

Thirdly, teacher-based rated the least among other approaches used with $25.6 \%(n=19)$. As teacher-based approach focuses on teacher autonomy in teaching practice and in professional development, as well as on teacher's role in supporting autonomy (Benson, 2001, 2013; Borg \& Busaidi, 2012; Feryok, 2013), this suggests that quite a number of the lecturers are aware and accept the responsibility for their teaching. This perception they hold impact on their attitudes towards the 
INTERNATIONAL JOURNAL OF ACADEMIC RESEARCH IN BUSINESS AND SOCIAL SCIENCES

Vol. 8, No. 12, Dec, 2018, E-ISSN: 2222-6990 @ 2018 HRMARS

implementation of learner autonomy in their teaching practices (Aoki, 2008; Borg \& Busaidi, 2012). As agreed by many researchers, this explains the interdependence between teachers and students where learner autonomy depends on teacher autonomy.

The second part of the research question asked the ESL lecturers to give examples of strategies they used to promote learner autonomy and 58 lecturers provided the examples. A list of 126 strategies were generated and from the analysis, seven categories were found to be dominant. A break-down of these main categories is illustrated in Figure 2.

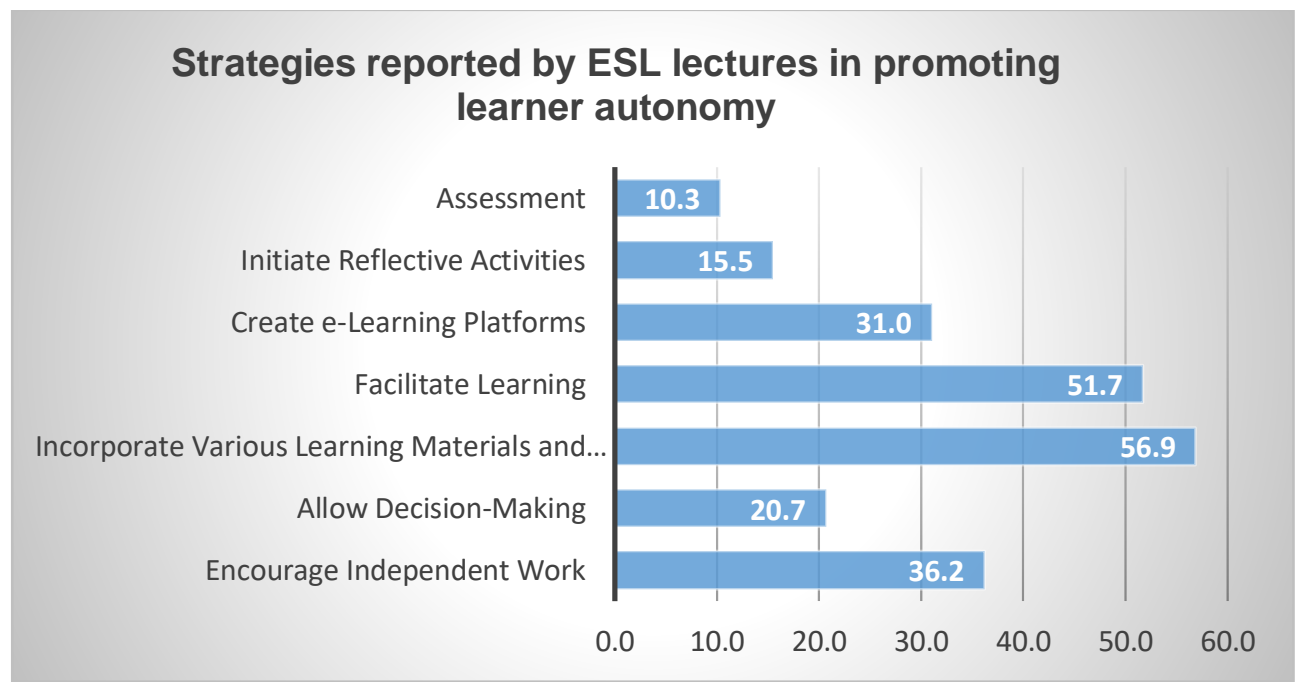

Figure 2. The strategies reported by ESL lecturers in promoting learner autonomy

As illustrated in Figure 2, the seven broad categories for the strategies used are, incorporate various learning materials and resources, facilitate learning, encourage independent work, create elearning platforms, allow decision-making, initiate reflective activities and finally through assessments. 'Incorporate various learning materials and resources' was the most commonly used strategy reported by the ESL lecturers (56.9\%), followed by 'facilitate learning' with $51.7 \%$. This finding provides further insights on the ESL lecturers' various strategies used in promoting learner autonomy to their students who are adult learners. Students' different learning styles and needs could be the influential factors for the strategies used by the ESL lecturers in their teaching practice. Below are the common sub-categories which reflect in specific of the strategies used by these ESL lecturers in promoting learner autonomy for all the approaches they have reported initially (refer Table 1). 
INTERNATIONAL JOURNAL OF ACADEMIC RESEARCH IN BUSINESS AND SOCIAL SCIENCES Vol. 8, No. 12, Dec, 2018, E-ISSN: 2222 -6990 @ 2018 HRMARS

Table 3. Summary of strategies used in promoting learner autonomy.

\begin{tabular}{|c|c|}
\hline Strategies & Respondents' Responses \\
\hline $\begin{array}{l}\text { Incorporate various } \\
\text { learning materials and } \\
\text { resources }\end{array}$ & $\begin{array}{l}\text { "Utilize the mobile phones in the learning process". (R22) } \\
\text { "Encourage them to do extensive reading in the library".(R53) } \\
\text { "Newspapers, books and magazine, articles".(R59) } \\
\text { "Using social media like Facebook, Instagram and Twitter". (R58) }\end{array}$ \\
\hline Facilitate learning & $\begin{array}{l}\text { "Guide by the side, assist via e-mail, mentoring and monitoring, chart } \\
\text { their progress". (R63) } \\
\text { "Share with them the techniques, means and ways".(R54) } \\
\text { "Students can refer to the lecturer if they need or want to".(R6) } \\
\text { "Lecturer guides and provides learning experience".(R43) }\end{array}$ \\
\hline $\begin{array}{l}\text { Encourage independent } \\
\text { work }\end{array}$ & $\begin{array}{l}\text { "Provide opportunities to learn beyond the classroom".(R71) } \\
\text { "Give them task that requires them to work independently".(R47) } \\
\text { "I give space for them to work independently and present their } \\
\text { thoughts based on their personal experience". (R31) }\end{array}$ \\
\hline Create e-learning platforms & $\begin{array}{l}\text { "Create Edmodo as a platform for interaction beyond class } \\
\text { hour".(R4O) } \\
\text { "Present their idea in class and upload in the Edmodo".(R23) } \\
\text { "Learning through discovery, doing Moodle assignment".(R18) }\end{array}$ \\
\hline Allow decision making & $\begin{array}{l}\text { "In planning certain programs, I'll give them chance to discuss and } \\
\text { come out with their decisions".(R51) } \\
\text { "Giving them the full chance of attempting the coursework".(R57) } \\
\text { "They are free, the way the want to present tasks".(R48) } \\
\text { "Students are given opportunities to make decisions on certain part of } \\
\text { T-L activities".(R68) }\end{array}$ \\
\hline Initiate reflective activities & $\begin{array}{l}\text { "Allowing them to share their thoughts openly".(R33) } \\
\text { "Sharing sessions after task completion".(R2) } \\
\text { "Trainees are actively involved through reflection of their classroom } \\
\text { practices during practicum. This practice provides the trainees } \\
\text { opportunity for self-development".(R16) }\end{array}$ \\
\hline Assessment & $\begin{array}{l}\text { "Different tasks are provided to different groups of students".(R49) } \\
\text { "I prepare individual and group tasks". (R72) } \\
\text { "A lot of task-based, ISL, info search, presentations". (R64) }\end{array}$ \\
\hline
\end{tabular}

\section{Conclusion}

Looking from the ESL lecturers' perspectives at Institute of Teacher Education, this study provided insights on their practices especially the approaches and strategies used in promoting learner autonomy. This study is significant, particularly in teacher training context in Malaysia in tandem with the emphasis for teachers to focus on getting students to be independent and autonomous learners as highlighted in Malaysian Education Blueprint (MEB 2013-2025). Studies on ESL learner autonomy at the teacher training context is scarce, hence this study recommends for more studies to be carried out on learner autonomy looking from the perspectives of ESL learners or 
lecturers in Institute of Teacher Education. The results of the study indicated that ESL lecturers employed multiple strategic approaches in promoting learner autonomy based on their beliefs and understanding of the concept of learner autonomy, hence is manifested through the approaches and strategies used in their teaching practices. More similar studies should be conducted with qualitative methods to have in depth views on strategies used by the ESL lecturers in promoting learner autonomy. As to produce quality teacher trainees, it would be great for ITE to design the training programs that emphasize on the pedagogical knowledge and skills in fostering learner autonomy in the English language classroom as these future ESL teachers will be serving in primary schools nationwide for the next 30-35 years.

\section{Acknowledgement}

We are grateful to Dr. Nurul Fadly Habidin for his guidance and support in the article writing process. We would also like to thank those who have directly or indirectly contributed throughout the project and writing phase.

\section{Corresponding Author}

Fauziah Ismail is currently a PhD student in Faculty of Education at Universiti Kebangsaan Malaysia. She has been a lecturer, teaching English in Institut Pendidikan Guru Kampus Pendidikan Islam, Selangor since 2008. Her main research interests include learner autonomy and teacher training.

\section{References}

Aoki, N. (2008). Teachers' stories to improve theories of learner/teacher autonomy. Independence, 43, 15-17.

Arikan, A., \& Bakla, A. (2011). Learner autonomy online: Stories from a blogging experience. In D., Gardner (Ed.), Fostering autonomy in language learning (pp. 240-251). Gaziantep: Zirve University.

Benson, P. (2011) Teaching and Researching Autonomy in Language Learning. 2nd Edition Harlow: Longman/Pearson Education.

Benson, P. (2013). Teaching and researching autonomy (2nd ed.). New York: Routledge

Borg, S., \& Al-Busaidi, S. (2012). Learner Autonomy: English Language Teachers' Beliefs and Practices. London: British Council.

Feryok, A. (2013). Teaching for learner autonomy: the teacher's role and sociocultural theory. Innovation in Language Learning and Teaching, 7(3), 213-225

Dwee, C. Y., \& Anthony, E. M. (2017). Learner Autonomy in University English Class-rooms: Teachers' Perceptions and Practices. International Journal of Applied Linguistics and English Literature, 6(2), 19-25.

Hasim, Z., \& Zakaria, A. R. (2016). ESL Teachers' knowledge on learner autonomy. In Knowledge, Service, Tourism \& Hospitality: Proceedings of the Annual International Conference on Management and Technology in Knowledge, Service, Tourism \& Hospitality 2015 (SERVE 2015). CRC Press.

Holec, H. (1981). Autonomy and foreign language learning. Oxford: Pergamon

Littlewood, W. (1999). Defining and developing autonomy in East Asian contexts. Applied Linguistics, 20(1), 71-94

Luzón, M. J., \& Ruiz-Madrid, M. N. (2008). Learning to learn in a digital context: Language learning web tasks for an autonomising "reading" competence. CORELL: Computer Resources for Language Learning, 2, 28-45.

Malaysia Education Blueprint 2013-2025 (2013). Putrajaya, Malaysia: Ministry of Education.

Tassinari, M. G. (2012). Evaluating learner autonomy: A dynamic model with descriptors. Studies in Self-Access Learning Journal, 3(1), 24-40.

Yunus, M. M., \& Arshad, N.D. (2014). ESL Teachers' Perceptions toward the Practices and Prospects of Autonomous Language Learning. Canadian Center of Science and Education, 11 (2). 